\title{
Biofilms in drinking water: problems and solutions
}

Cite this: RSC Advances, 2013, 3, 2520

Received 22nd September 2012,

Accepted 5th November 2012

DOI: $10.1039 / \mathrm{c} 2 \mathrm{ra} 22243 \mathrm{~d}$

www.rsc.org/advances

\author{
Lúcia Chaves Simões*ab and Manuel Simões ${ }^{b}$
}

\section{Introduction}

Water is the most common and important chemical compound on Earth. It is essential for all socio-economic development and for maintaining healthy ecosystems. Only

${ }^{a}$ IBB-Institute for Biotechnology and Bioengineering, Centre of Biological Engineering, University of Minho, Campus de Gualtar 4710-057 Braga, Portugal. E-mail: luciachaves@deb.uminho.pt; Fax:00351 253678986; Tel: 00351253604404 ${ }^{b}$ LEPAE, Department of Chemical Engineering, Faculty of Engineering, University of Porto, Rua Dr Roberto Frias, s/n, 4200-465 Porto, Portugal approximately $2.6 \%$ of global water (i.e., $1.4 \times 10^{9} \mathrm{~km}^{3}$ ) is freshwater and, consequently, available as potential drinking water (DW). The availability of safe DW has been the most critical factor for survival during the development of life. ${ }^{1} \mathrm{DW}$ or potable water is water of sufficient quality to ensure that it can be consumed or used without risk of immediate or longterm harm. The provision of safe DW is considered a top priority in civilized societies. Microbiologically and chemically contaminated DW has been linked with several health problems. ${ }^{2}$ The consumption of contaminated DW can cause

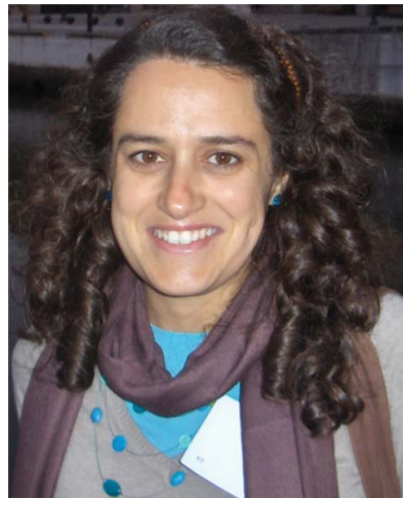

Lúcia Chaves Simões
Lúcia Chaves Simões graduated in Biological Engineering and has a Masters degree in Environmental Technology and $\mathrm{a} P \mathrm{P}$ in Chemical and Biological Engineering from Minho University. Currently, she is a post-doctoral researcher at IBB$C E B$, University of Minho in collaboration with LEPAE-FEUP, University of Porto, supported by the Portuguese Foundation for Science and Technology. Her main research interests focus on the mechanisms of drinking water biofilm formation and biofilm control.

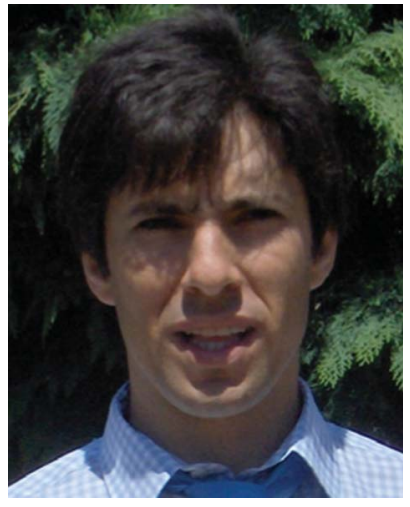

Manuel Simões studied Biological Engineering and received $a \mathrm{PhD}$ in Chemical and Biological Engineering from the University of Minho. Following post-doctoral work at the same university, he joined CITAB at the University of Trás-os-Montes e Alto Douro as a research fellow. Since 2008, he has been an Assistant Professor and member of the LEPAE in the Department of Chemical Engineering of the Faculty of Manuel Simões Engineering at the University of Porto. His main research interests focus on the mechanisms of biofilm formation and their control with antimicrobial agents. 
a wide range of diseases and health-related problems in all people or in those more susceptible, like infants, young children, elderly or unwell people or those who are immunecompromised.

Recognized harbours of pathogenic microbial contaminants in DW distribution systems (DWDS) are biofilms that develop in the inner walls of pipes of distribution networks. ${ }^{1,3,4}$ In these microbial consortiums, pathogenic microorganisms are protected from stress conditions (chlorine, shear stress, temperature), which allows them to remain viable. ${ }^{5}$ Hence, when detachment of portions of the biofilms occurs, they enter bulk water, which permits a possible outbreak of disease..$^{5-7}$ It is well known that biofilms constitute one of the major microbial problems in DWDS, which contributes to the deterioration of water quality. ${ }^{8}$ However, their elimination from these systems is almost impossible. But several aspects can be considered in order to prevent and control their growth, particularly the nutrient content of water, the concentration of residual disinfectant, the hydrodynamic conditions of the network, the pipe materials and their conservation conditions, the diversity of microorganisms present in DWDS and environmental factors, like $\mathrm{pH}$ and the temperature of water. ${ }^{9}$

Biofilms in drinking water distribution systems (DWDS) have been studied in an intensive way in the last decades. Therefore, there is a wide assortment of reviews published on this topic covering aspects, such as the hygienic quality of DW,,$^{1,8,10-20}$ as well as its development ${ }^{8,18,21-24}$ and control. ${ }^{18,25,26}$ This review provides new and relevant information on the public health problems associated with the presence of biofilms in DWDS and describes current and emergent strategies for their control.

\section{Drinking water quality and public health}

There are many countries in the world today where water scarcity, rather than quality, is the major issue in relation to health. Access to adequate and safe DW should be a basic human right, yet today there are nearly 1 billion people globally that do not have access to sufficient safe DW. ${ }^{27-30}$ Many of these are managing on as little as $5 \mathrm{~L}$ a day for all their drinking, washing and cooking needs. In contrast, the developed world uses on average between $150 \mathrm{~L}$ and $580 \mathrm{~L}$ each day, with the U.K. (150 L) and the United States (580 L) having one of the lowest and highest per capita water consumption rates, respectively. International guidelines set out that the minimum requirement for water has been estimated at $50 \mathrm{~L}$ per capita per day, which is the so-called water poverty threshold. ${ }^{28}$ DW quality, especially in terms of pathogens, cannot be isolated from sanitation alone and a total of 2.6 billion people currently lack adequate sanitation facilities. The various health problems created by the lack of access to clean DW and proper sanitation have a daily impact on $50 \%$ of the population of developing countries. ${ }^{28,29}$
The concept of safe DW on tap is a luxury not shared by the majority of the world's population and is taken for granted by the majority of those who have it. More than a billion people have no access to safe DW and, over the past 2 decades, over 2 million people, mainly children, have died unnecessarily every year due to water-related diarrhoea. In the developing world, it is estimated that $45 \%$ of all deaths are due to contaminated DW. More than $80 \%$ of the world's wastewater is not collected or treated, causing millions of deaths from diarrhoea-related diseases every year in the developing world. ${ }^{30}$ In these affected countries, chemical contamination is insignificant compared to the need for pathogen-free DW. Safety, in this context, is relative and the success of preventing waterborne diseases in the developed world has focused on other contaminants. In recent years, there has been a growing awareness of contamination from naturally occurring inorganic chemicals in groundwater (arsenic, radon and fluoride) and also from anthropogenic activities involving agriculture, industry and urban development (lead, nitrate and pesticides). ${ }^{2}$ More recently, emergent contaminants (human hormones, antibiotics, personal care products, endocrine disruptors and illicit drugs) appear in surface waters and the conventional DW treatment processes are inefficient at removing these micropollutants. ${ }^{31,32}$ Yet, the risk from microbial pathogens remains ever present in the developed world and a daily challenge for the water treatment engineers and scientists. Waterborne diseases are one of the most important water-associated health problems. Waterborne diseases refer to any illness caused by the utilization of DW contaminated by human or animal faeces, which contain pathogenic microorganisms, or by chemical products. Waterborne pathogens are disease-causing bacteria, protozoa, virus or helminths that are transmitted to people when they consume untreated or inadequately-treated water and are listed in Table 1. The pathogens that may be transmitted through contaminated DW are diverse in characteristics, behaviour and antimicrobial resistance (Table 1). Bacteria are generally the group of pathogens that are most sensitive to disinfection. However, several environmental nontuberculous mycobacteria showed high resistance to chlorine, while others (Pseudomonas aeruginosa, Staphylococcus aureus and Francisella tularensis) showed a moderate resistance. If these pathogenic microorganisms are not removed by disinfection and reach the consumer's tap, they may cause outbreaks of disease within the community. An outbreak of waterborne disease is generally defined as a situation in which at least two people experience a similar illness after exposure to water, where the evidence suggests a probable water source. The occurrence of outbreaks of waterborne diseases is not limited to developing countries; affluent countries are also affected. ${ }^{33-36}$ Table 2 shows some disease outbreaks in several parts of the world caused by the consumption of contaminated water in the last 150 years. While gastroenteritis is the most known disease associated with waterborne outbreaks in developed countries, there are many others: e.g., cholera, typhoid fever, meningitis, encephalitis, dysentery, hepatitis, 
Table 1 Pathogens associated with waterborne diseases and their resistance to disinfection by chlorine $e^{2,27,37}$

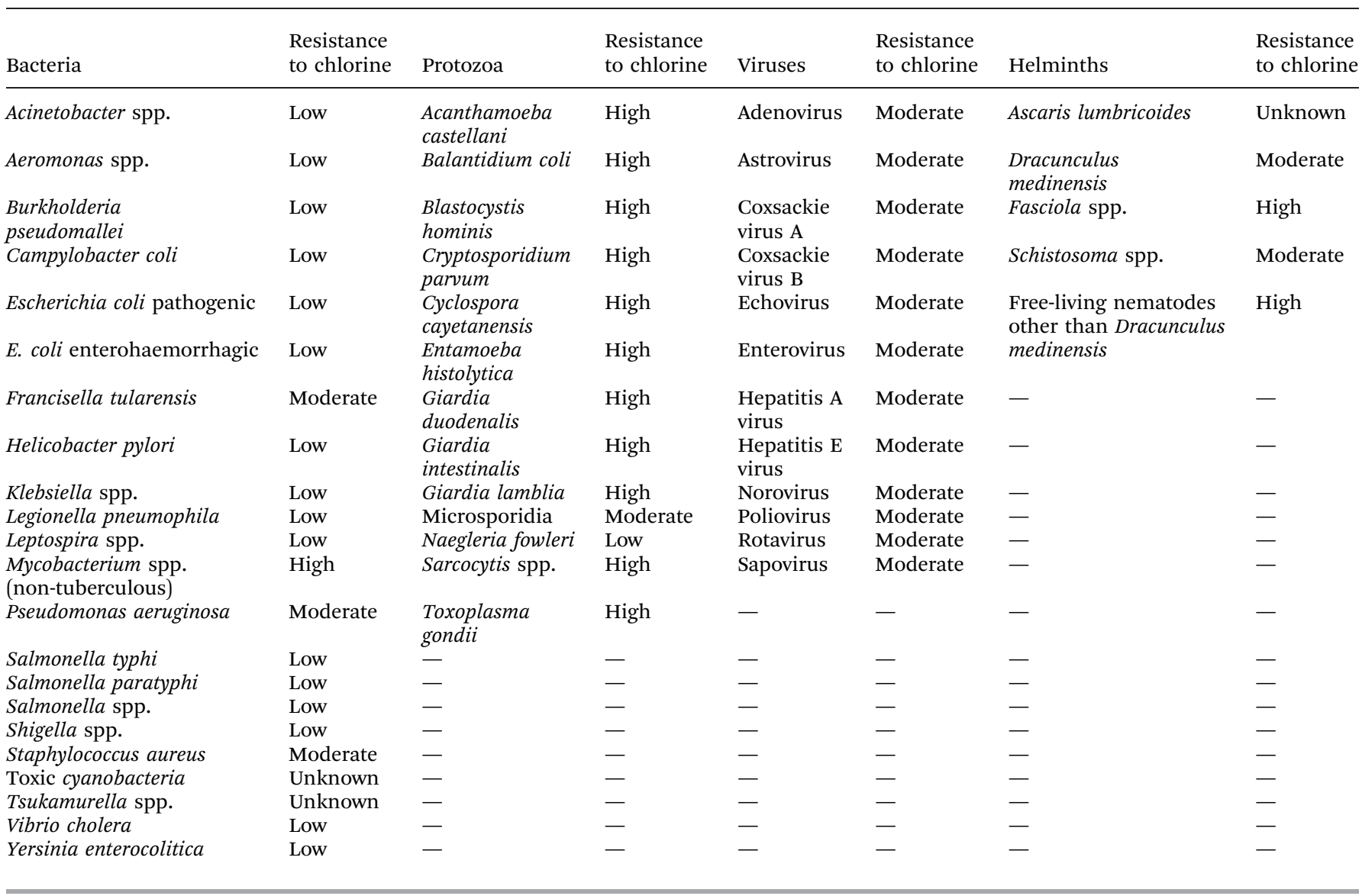

legionellosis, pulmonary illness, poliomyelitis, leptospirosis, giardiasis and salmonellosis., 27,37

Although water-related diseases are rarely deadly in developed countries, there are several authors who report that DW consumption has numerous health risks attributed to pathogenic bacteria, protozoa and virus. ${ }^{38-43}$ Several outbreaks with public health risks occurred due to malfunctioning DW treatment plants and distribution networks, which failed to maintain an adequate level of disinfectant to prevent the growth of pathogens and/or harboured the pathogens. In this millennium, some reported waterborne outbreaks have been due to Escherichia coli O157:H7, Campylobacter spp., Helicobacter pylori, $P$. aeruginosa, Salmonella paratyphi, Cryptosporidium parvum, Giardia and viruses (e.g., norovirus, calcivirus, enterovirus) in Canada, France, Italy, England, Finland, Switzerland, Northern Ireland, Norway, Belarus, New Zealand, Poland and the United States. ${ }^{34-36,44-55}$

Despite the numerous reported outbreaks, these numbers are surely underestimated as not all are recognized, investigated or reported. Nowadays, these health risk events still occur too frequently: ${ }^{56-58} 31$ events in 2000-2001 and 30 events in 2003-2004 in the USA. From 1920 to 2002, at least 1870 outbreaks were associated with DW in the United States, an average of 22.5 per year and 883806 illnesses, which amounts to an average of 10648 cases each year. ${ }^{34}$ These outbreaks were attributed to microbial contaminations with viruses (norovirus, hepatitis A virus), protozoa (Cryptosporidium spp., Giardia spp., Naegleria fowleri) and pathogenic bacteria (Salmonella typhimurium, Vibrio cholerae, Legionella spp., Shigella spp., E. coli 0157:H7 and Campylobacter jejuni) or to chemical/toxins. According to a World Health Organization (WHO) report, ${ }^{59}$ between 2000 and 2007 in 14 European countries (Belgium, Czech Republic, Croatia, Estonia, Finland, Greece, Hungary, Italy, Lithuania, Norway, Slovakia, Spain, Sweden and the United Kingdom), there were 354 outbreaks of waterborne diseases related to DW, resulting in over 47617 episodes of illness. All the participating countries had a routine surveillance system for waterborne outbreaks, based on a legal framework. The most common causative agents were bacteria (Campylobacter, Aeromonas spp. and Shigella sonnei) and were responsible for 163 (44.9\%) outbreaks and $33.3 \%$ of disease cases. Viral agents were implicated in 136 outbreaks $(37.5 \%)$ and $49.4 \%$ of cases of disease, while protozoa caused 17 outbreaks $(4.7 \%)$ and $9.9 \%$ of disease cases. Ten cases were caused by chemical contamination $(0.2 \%)$, while, in 37 cases $(7.1 \%)$, an unknown microbial agent was implicated. At least 325 waterborne outbreaks worldwide were due to parasitic protozoan. ${ }^{37}$ Control of pathogens in DW is apparently straightforward, but poverty combined with water scarcity is a devastating combination. Adequate supplies 
Table 2 Some reported outbreak of diseases due to microbially contaminated DW

\begin{tabular}{|c|c|c|c|c|}
\hline Year & Disease outbreak & City/Country & Additional information & Ref. \\
\hline 1854 & Cholera outbreak & London, England & $\begin{array}{l}\text { Identified by Dr John Snow as originating from contaminated } \\
\text { water from the Broad street pump. This can be regarded as a founding } \\
\text { event of the science of epidemiology. }\end{array}$ & 171 \\
\hline
\end{tabular}

1980

Hepatitis A

1985

Typhoid fever outbreak Israel followed by a large outbreak of dysentery

Cryptosporidiosis outbreak

1993

Cryptosporidium outbreak outbreak

Campylobacteriosis outbreak

1998

Viral gastroenteritis outbreak
E. coli outbreak

2000/2001 Cryptosporidiosis outbreaks

Norovirus gastroenteritis Stockholm, outbreak

Enterovirus outbreak

Giardiasis outbreak

Gastroenteritis

outbreak with

multiple etiologies

Gastroenteritis

outbreak

Gastroenteritis outbreak with multiple aetiologies

Giardiasis outbreak

Norovirus gastroenteritis outbreak

Cholera outbreak Bengal, India
Sweden

Western
Georgia, USA
Milwaukee, USA

Minnesota, USA

Finland

Switzerland

Walkerton, Ontario, Canada

Belfast, Northern Ireland

Vitebsk, Belarus

Bergen, Norway

South Bass Island, Sar Ohio, USA

New Zealand

Denmark

California, USA

Sweden
Outbreaks in the north of Israel, associated with a contaminated municipal water supply.

Caused by the public water supply of which the filtration system was contaminated.

Caused by Cryptosporidium oocysts that passed through the filtration system of one of the city's water treatment plants. In two weeks, approximately 403000 of an estimated 1.61 million residents in the Milwaukee area became ill and at least 104 deaths were recorded, mostly among the elderly and immuno-compromised people.

369 cases of cryptosporidiosis caused by a contaminated fountain in the Minnesota zoo. Most of the sufferers were children.

A non-chlorinated municipal water supply was blamed for a campylobacteriosis outbreak in northern Finland.

In a Swiss village of 3500 inhabitants; more than $50 \%$ were affected. The DW was highly contaminated with enteric viruses.

Seven people died from contaminated DW. Hundreds suffered from the symptoms of disease, not knowing if they too would die.

The $3 \mathrm{DW}$-associated outbreaks occurred in the greater Belfast area over a 1-year period and were caused by contamination of the DW supply by seepage of raw sewage and wastewater into the DWDS.

Affected at least 200 people. The source of illness was contaminated DW obtained from private wells. This was the first reported waterborne outbreak of viral gastroenteritis in Sweden.

Enteroviral infection (Coxsakie B4) in Vitebsk due to pollution of the water supply by enteroviruses.

fecal microbes, including $E$ coli, $C$. jejuni, Salmonella, and Giardia species. The sewage-contaminated groundwater was the likely source of this large outbreak.

The source was a DW supply contaminated by human sewage. This outbreak has been linked to norovirus detected in a community water supply.

Contaminated DW.

Occurred at a private recreational camp after the installation of a slow-sand filtration water-treatment system. 26 people had laboratory-confirmed giardiasis; another 24 had a giardiasis-like illness with no stool test.

Almost 200 inhabitant of a small Swedish village fell ill. Contamination of one of the wells supplying the public water network was thought to be the source of the outbreak. This norovirus outbreak was linked to a municipal DW supply.

Following Cyclone Aila, an increased number of diarrhoea cases were reported. 185 In total, 1076 patients and 14 deaths were quantified. Contaminated DW was the probable source of the cholera outbreak. 
of clean water, combined with adequate sanitation and improved hygiene standards, would significantly reduce the incidence of waterborne diseases.

\section{Biofilms in drinking water distribution systems}

Biofilm formation, also known as biofouling, is a wellrecognized problem in the water industry. Biofouling, in general, refers to the undesirable accumulation of biotic matter on a surface. It has been shown to be of considerable hygienic, operational and economical relevance, not only in DWDS but also in other purified water supply systems, such as dental unit waterlines, ${ }^{60-62}$ dialysis units, ${ }^{63,64}$ laboratories, ${ }^{65}$ reverse osmosis systems, ${ }^{66}$ pharmaceutics, ${ }^{67}$ the semiconductor industry ${ }^{68,69}$ and even the International Space Station water recovery and management system. ${ }^{70}$

Many problems in DWDS are microbial in nature, including biofilm growth, nitrification, microbially-mediated corrosion and the occurrence and persistence of pathogens., ${ }^{6,71-74}$ Biofilms are suspected to be the primary source of microorganisms in DWDS that are fed with treated water and have no pipeline breaches and are of particular concern in older DWDS. ${ }^{75,76}$ About $95 \%$ of the total biomass in water is estimated to attach to pipe walls, while only $5 \%$ is in the water phase. ${ }^{77}$ Therefore, microbial growth in biofilms is highly relevant for water quality since they may directly affect cell density in the bulk phase.

DW biofilms are composed of complex microbial communities functionally organized and embedded in a gelatinous matrix of extracellular polymers excreted by microorganisms (Fig. 1a). Extracellular polymers, also known as extracellular polymeric substances (EPS), are the key substances keeping biofilm organisms together, gluing them to the surface and providing protection against agents of stress. Any inorganic particle passing nearby (e.g. corrosion products, clays, sand, etc.) may also be incorporated in the biofilms (Fig. 1b) increasing its "mechanical strength". ${ }^{78,79}$ Bacteria are generally dominant in biofilms due to their high growth rates, small size, adaptation capacities and the ability to produce EPS. ${ }^{80}$ However, viruses, protozoa, fungi and algae may also be present in DW biofilms. ${ }^{8,81,82}$

By adopting the sessile mode of life, biofilm-embedded microorganisms enjoy a number of advantages over their planktonic counterparts. One advantage is the ability of the extracellular polymeric matrix, which they excrete, to capture and concentrate environmental nutrients, such as carbon, nitrogen and phosphate. ${ }^{83-85}$ Another advantage of the biofilm mode of growth is that it enables resistance to a number of removal strategies, particularly antimicrobial and mechanical stresses. ${ }^{86-89}$ DWDS disinfection with chlorine dioxide and chlorine, for example, can reduce the concentration of planktonic bacteria, but have little to no effect on the concentration of biofilm bacteria. ${ }^{90,91}$ Fig. 2 depicts the effects of chlorine at $10 \mathrm{mg} \mathrm{l}^{-1}$ on the viability of DW multispecies biofilms and shows the presence of viable cells after treatment and significant recovery $24 \mathrm{~h}$ later. This inherent resistance of biofilms to antimicrobials can be mediated through very low metabolic levels and drastically downregulated rates of cell division of the deeply embedded microorganisms. Furthermore, biofilms act as a diffusion barrier to antimicrobial agents, slowing penetration. ${ }^{89,92-94}$ Antimicrobial agents interact with EPS components, reducing the agent's concentration and their effectiveness ("reaction-diffusion-inhibition"). ${ }^{86,89,93}$ Another advantage of living in a biofilm is the possibility of metabolic interactions between bacteria with different physiological requirements. ${ }^{93,95}$ This will promote the formation of spatial niches in a biofilm in response to environmental conditions and the activity of their neighbours in order to optimize the nutritive resources. ${ }^{95,96}$ Bacterial communication through excreted signalling molecules is another advantage of living in biofilm communities. ${ }^{97,98} \mathrm{~A}$ significant advantage of the biofilm mode of growth is the potential for dispersion via detachment. ${ }^{99,100}$ Under the direction of fluid flow, detached microorganisms travel to (a)

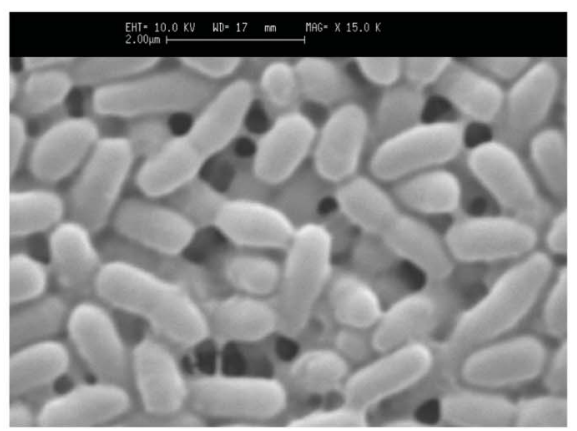

(b)

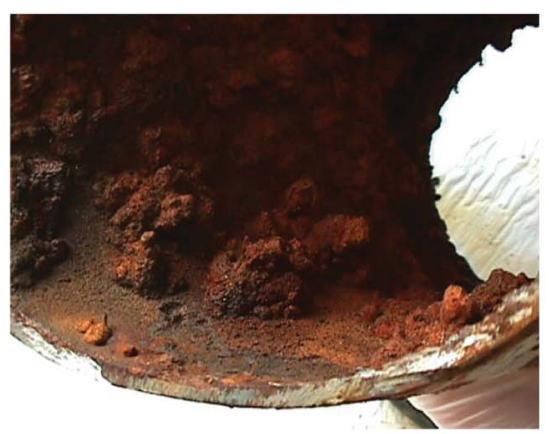

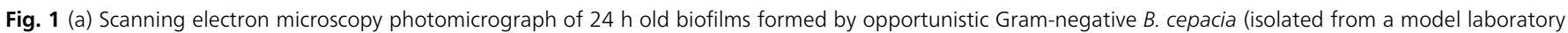

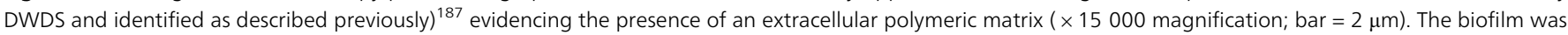
developed in R2A broth as a growth medium on polystyrene surfaces of microtiter plates. ${ }^{91}$ (b) Ductile iron pipe section from a DWDS with a biofilm and high amounts of corrosion products. This section of DWDS pipe was obtained as result of a pipe break in the DWDS. 
(a)

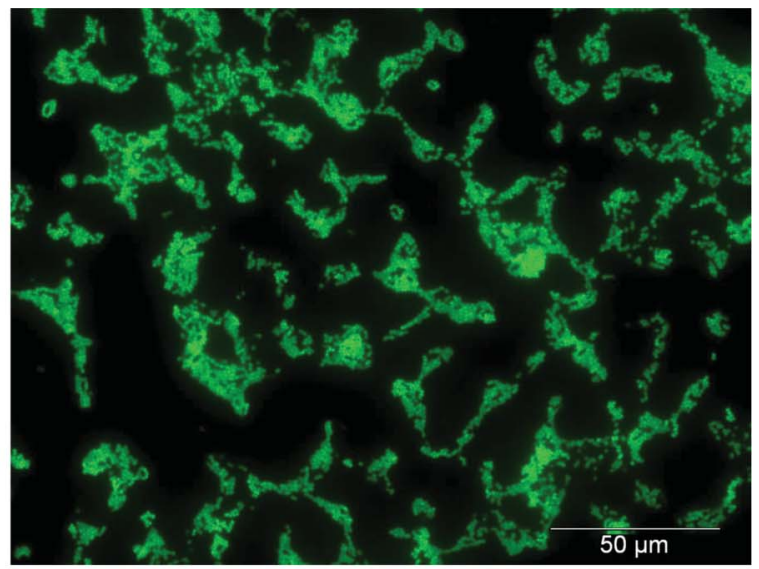

(b)

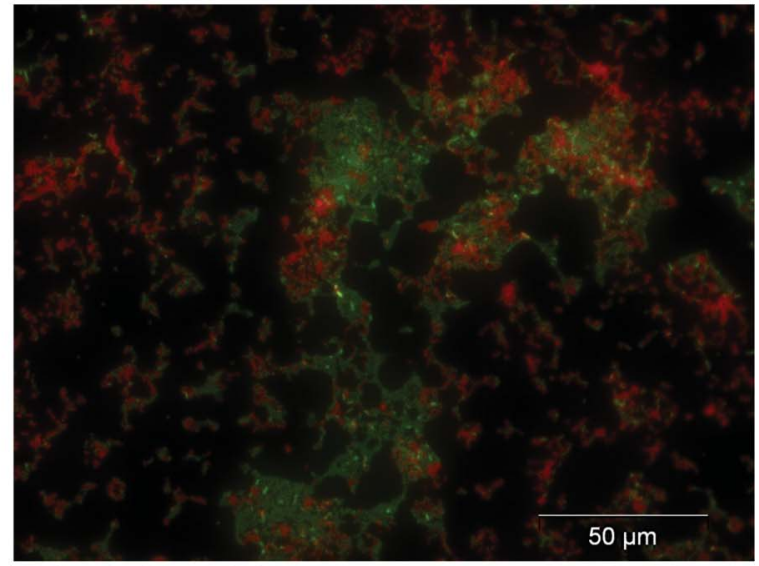

(c)

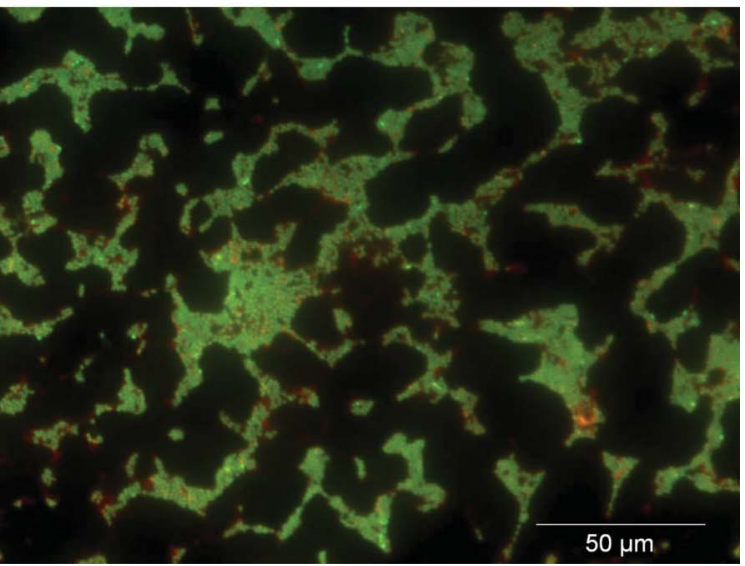

Fig. 2 Effects of chlorine disinfection on the viability of DW multispecies biofilms and their ability to recover after treatment. The epifluorescence photomicrographs show the biofilms (a) before treatment with $10 \mathrm{mg} \mathrm{I}^{-1}$ sodium hypochlorite; (b) immediately after and (c) $24 \mathrm{~h}$ later. Magnification, $\times 400$; bar $=50 \mu \mathrm{m}$. Viable cells are green and non-viable cells are red. The synthetic DW multispecies biofilm were composed of $A$. calcoaceticus, $B$. cepacia, Methylobacterium spp., M. mucogenicum, S. capsulata and Staphylococcus spp. and were developed in R2A broth as a growth medium for $72 \mathrm{~h}$ in 96 -well-flat microtiter plate and then the disinfectant was applied for 1 h. ${ }^{91}$ After that, biofilm recovery from disinfection was assessed after $24 \mathrm{~h}$. The viability of multispecies biofilms was assessed with an L-7012 Live/Dead BacLight bacterial viability kit (Invitrogen/Molecular Probes) using epifluorescence microscopy. The BacLight kit is composed of two nucleic acid-binding stains (SYTO $9^{\text {TM }}$ and propidium iodide). SYTO $9^{\mathrm{TM}}$ penetrates all bacterial membranes and stains the cells green, while propidium iodide only penetrates cells with damaged membranes and the combination of the two stains produces red fluorescing cells. other regions to attach and promote biofilm formation on clean areas. ${ }^{101}$ Therefore, this advantage allows a persistent bacterial source population, usually resistant to antimicrobial agents, while at the same time enabling the continuous shedding to promote bacterial spread.

The interaction of pathogens with other biofilm microorganisms has been a principle concern in DWDS. Biofilms formed within potable-water systems may contain bacterial pathogens, such as Legionella pneumophila and coliforms of intestinal and non-intestinal origin. ${ }^{2,76,102}$ Protozoa are commonly found within DWDS biofilms and have been associated with pathogen persistence and invasiveness. ${ }^{103}$ Pathogens, such as L. pneumophila, Mycobacterium spp., P. aeruginosa, Klebsiella spp., Burkholderia spp., Giardia and Cryptosporidium, among others (Table 1), are transmitted by contaminated water and biofilms are a good candidate as they can act as a protective niche for their survival. ${ }^{1,4,104}$ Such findings demonstrate the essential role of an efficient disinfection plan to control microorganisms in the bulk phase and their biofilms in order to provide high quality DW. Fig. 3 summarizes relevant information about the problems of biofilm formation in DWDS and the main control measures.

\section{Biofilm prevention and control in drinking water distribution systems}

Biofilm formation can be limited by: (i) minimizing the concentration of organic matter entering the distribution system; (ii) ensuring the material from which the pipework and fittings are made so they are both chemically and biologically stable; (iii) prevention of water stagnation and sediment accumulation within the distribution systems; (iv) maintenance of a sufficient disinfectant level throughout the distribution system. ${ }^{2,105}$

\subsection{Pre-treatment}

The maintenance of sufficient residual chlorine in the system is difficult when the water supplies have a high chlorine demand due to the presence of organic matter. Consequently, one strategy to optimize DW quality is to reduce the content of organic matter and nutrients by more effective pre-treatments (ion-exchange, activated carbon, reverse osmosis, nanofiltration, ultrafiltration, microfiltration). However, to decrease the organic content would be a very expensive process and ineffective toward bacteria in DWDS, which are able to grow in oligotrophic environments. ${ }^{106-108}$ Ultra-pure water systems have been found to support the formation of biofilms, even if these systems have a lower organic content than DWDS. ${ }^{79,109}$ Nevertheless, some European countries, notably the Netherlands, Germany, Austria and Switzerland, have taken the approach of distributing high quality DW without the use of residual chlorine. The control of microbial growth in these countries is obtained through limitation of the nutrients essential for growth by more appropriate DW treatments (sedimentation, filtration, UV disinfection, ozone, peroxide), i.e., by the production of biologically-stable DW. In general, 


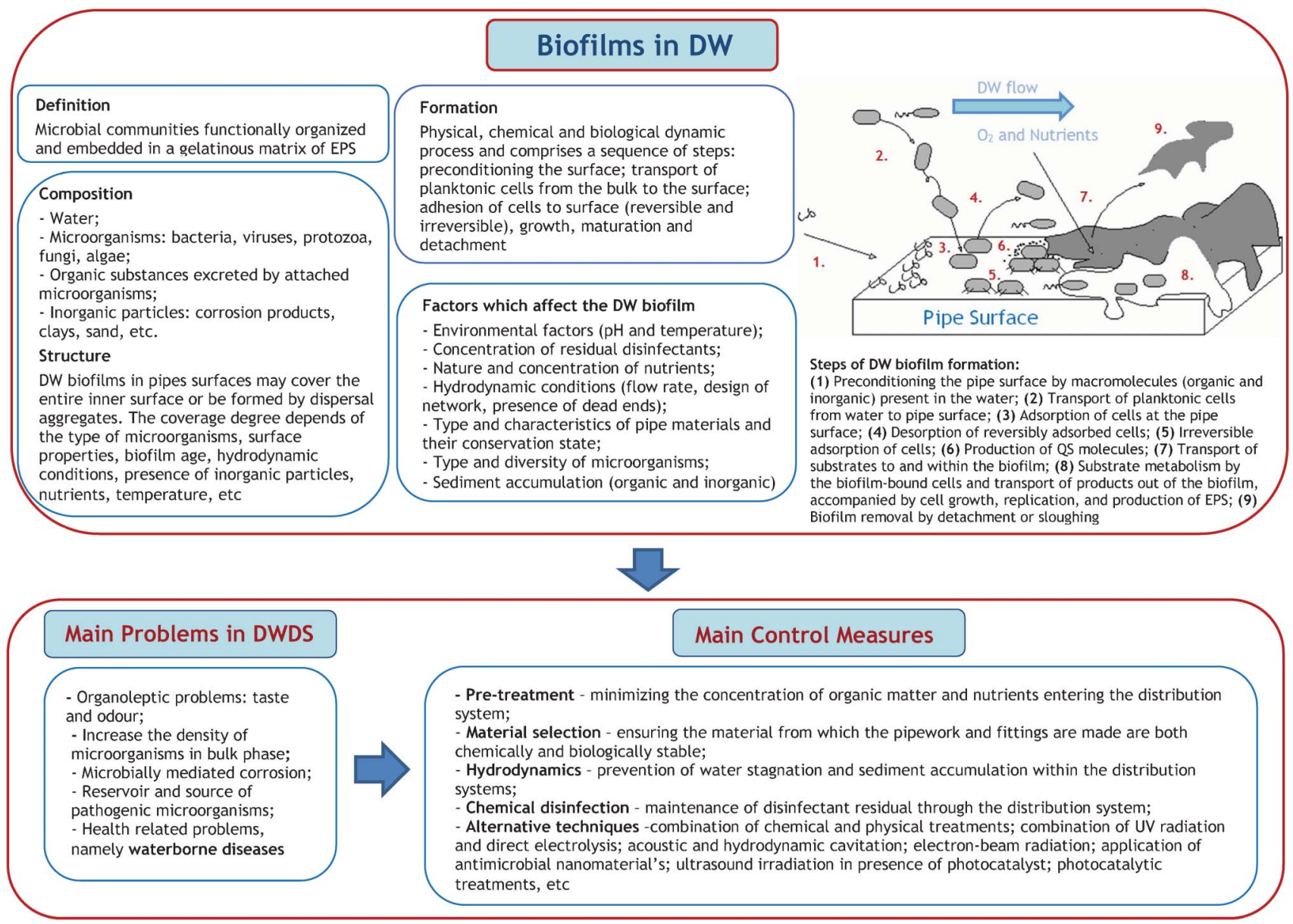

Fig. 3 Aspects of biofilm formation in DWDS: problems, development and control.

microorganisms need a $\mathrm{C}: \mathrm{N}: \mathrm{P}$ (carbon, nitrogen and phosphorous) ratio of $100: 10: 1$, where carbon is the growth-limiting nutrient. Thus, restricting the carbon concentration will decrease the propensity for microbial growth. ${ }^{110,111}$ Another preventative and promising strategy suggests the control of biofouling with an aqueous suspension of silver nanoparticles as a pre-treatment in water systems prior to the main treatment units, such as membrane filtration. ${ }^{112}$ It was not meant as a treatment for the eradication of existing or mature biofilms or as a disinfection process. The pretreatment with molecularly-capped silver nanoparticles presented in this study was able to control or retard biofilm formation on pipe surfaces. ${ }^{112}$

\subsection{Material selection}

Other preventative strategies have attempted to identify materials that do not promote or can even suppress biofilm formation. ${ }^{113}$ Different materials (ethylene-propylene, natural latex, stainless steel (SS), mild steel, polypropylene, polyethylene (PE), chlorinated polyvinyl chloride (PVC) and unplasticized PVC) were ranked according to their biofilm growth propensity, which unfortunately led to the conclusion that there is hardly any material that does not allow biofilm formation. ${ }^{113}$ There is, however, a considerable inhibitory effect (respiratory chain inhibition) of copper when compared to biofilm growth on other materials (high density PE, PVC, silicon, SS and glass). ${ }^{114-116}$ Concentrations of copper ions relevant to DWDS seem to induce a viable but non-culturable state in $P$. aeruginosa accompanied by a loss of culturability and cytotoxicity. ${ }^{117}$

The type and stability of the material used in DWDS is an important factor that can influence biofilm proliferation. There is a distinct development rate and microbial community structure of biofilms in different types of pipe. ${ }^{84,118}$ Bacteria are able to leach nutrients from the materials. ${ }^{113}$ A report stated that iron pipes can support 10 to 45 times more growth than plastic pipes. ${ }^{105}$ Also, iron pipes are more reactive with disinfectants and quench their antimicrobial effects. ${ }^{119}$ Thus, the type of material can also affect the disinfectant efficiency of biofilms. Biofilms grown on copper, PE, PVC and cementlined ductile iron were inactivated with a much lower amount of free chlorine or monochloramine than those grown on unlined iron surfaces. ${ }^{120-122}$ This was explained by the interaction of chlorine with iron. In cement-lined ductile iron, the cement provides a layer of protection for the iron against attack by chlorine. The pipe service age is another important factor influencing chlorine decay and this effect decreases in the following order: cast iron $>$ steel $>$ cement-lined cast iron 
$=$ cement-lined ductile iron $>\mathrm{PVC}=\mathrm{PE}^{123}$ Pipes in service for several years are subjected to significant corrosion (chemical and microbial-induced corrosion) and biofilm build-up and the chemical condition of the internal surface material of the pipe changes with service time. The consumption of chlorine is caused by chemical reactions of the antimicrobial with water constituents and with both the biofilm and tubercles formed on the pipe wall, as well as a reaction with the pipe wall material itself. ${ }^{123}$ This means that older pipes have more impact on the decay of chlorine concentration than new ones and cast iron pipes are probably the worst choice for DWDS due to their oxidation susceptibility.

\subsection{Hydrodynamics}

The distribution network must be planned to avoid zones of water stagnation or high water residence times in pipes and sediment accumulation. Pipes with long water residence times and dead-ends are associated with zones of high organic material sedimentation and, consequently, abundant biofilm formation. High bacterial numbers are associated with periods of non-flow or the storage of water in household pipes or tanks. ${ }^{75,124,125}$ On the other hand, biofilm growth in DWDS contributes to the accumulation of inorganic particles, like iron and manganese, in the distribution network, which are responsible for discoloured water, which are a persistent cause of customer dissatisfaction. ${ }^{126}$ Moreover, the sediment accumulation in DWDS may also decrease the disinfectant concentration. The application of operation measures should be taken into account in order to reduce sediment build-up in DWDS, particularly the optimization of pre-treatment, to minimize particles in DW entering the network, the application of sufficiently high flow velocities that may result in a selfcleaning network and regular flushing under specified conditions.

\subsection{Chemical disinfection and alternative techniques}

There is an urgent need to seek and develop new and alternative techniques for water disinfection to minimize the environmental and public health impacts of traditional techniques. WHO has stated that the "risks to health from disinfection by-products (DBPs) are extremely small in comparison with inadequate disinfection". 2 However, the development of safe and effective alternative disinfection methods is desirable. The main strategy to control biofilm accumulation in DWDS is chemical disinfection, particularly with chlorine, and an increase in its residual concentration through the network. Water disinfection is a process used to kill or irreversibly inactivate microorganisms that have passed through the treatment processes and to ensure microbiologically safe water through the DWDS. This is achieved by adding disinfectants in excess, particularly chlorine, which will maintain a disinfectant concentration during water distribution in order to control microbial accumulation in pipes and tanks. However, this has to be done carefully; high chlorine concentrations can cause organoleptic problems (strong odour and tastes), an increase in the production of carcinogenic DBPs, namely trihalomethanes and haloacetic acids (the most common), which are harmful to human health ${ }^{127,128}$ and lead to the selection of resistant microorganisms. Chlorine is a strong oxidizing agent and is the most commonly used disinfectant (Table 3) due to its effectiveness, high solubility, stability, ease of use and low cost. Furthermore, it can provide a disinfectant level in water that prevents or should prevent microbial regrowth. ${ }^{91}$ Currently, the residual concentration of free chlorine leaving the treatment plant should be less than $1.0 \mathrm{mg} \mathrm{l}^{-1}$ and nearer to $0.5 \mathrm{mg} \mathrm{l}^{-1}$. . The levels of disinfectants usually employed in DWDS are not sufficient to prevent the growth and development of microbial biofilms ${ }^{108}$ and, once biofilms are established on pipe surfaces, their elimination is almost impossible. As shown in Fig. 2, the application of $10 \mathrm{mg} \mathrm{l}^{-1}$ of sodium hypochlorite significantly reduced the number of viable cells in biofilms, but one day after disinfection the bacteria recovered their viability. Several factors can contribute to chlorine decay in DWDS and studies have been performed on this topic, including simulations in computer models. ${ }^{122,123,129,130}$ The addition of supplementary chlorine in strategic points along the distribution system (rechlorination stations) in order to maintain the disinfectant level is one further strategy to fight chlorine decay and guarantee microbial content control in water. However, there are a number of pathogenic microorganisms resistant to chlorine (Table 1). Effectively eliminating all the coliforms does not necessarily indicate that all other pathogenic microorganisms have also been destroyed. Pathogens normally present in DW, such as Mycobacterium spp., ${ }^{131} L$. pneumophila $^{132}$ and $H$. pylori, ${ }^{133}$ were found to be more resistant to chlorination than $E$. coli, the microorganism that is routinely tested as an indicator of faecal contamination for assessing DW quality. ${ }^{2,76}$ Therefore, the role of $E$. coli as an effective indicator of DW quality must now be questioned. Recent DW microbiological routine tests also include $L$. pneumophila and $P$. aeruginosa detection. Alternative or complementary methods to chlorine disinfection are recommended, like copper/silver ionization and ozone for Mycobacterium spp., ${ }^{131}$ superheating and chlorination for $L$. pneumophila $^{132}$ and UV irradiation, ozone, chlorine dioxide, reverse osmosis and microfiltration for some bacteria, viruses and protozoa resistant to chlorine (Table 1).

Disinfectants other than chlorine can be used in DWDS (Table 3). Chloramines are less effective than free chlorine and produce the same DBPs as chlorine, but in lower amounts. Their residual concentration is kept for longer periods and chloramines are not as reactive as chlorine with iron and corrosion products. ${ }^{120}$ Some reports suggest the combined use of chlorine and monochloramine in order to obtain higher disinfection and reduced DBPs. ${ }^{106,134}$ However, combined residual chlorine requires a contact time of a hundred times longer than free residual chlorine to achieve the same degree of elimination of pathogens. Chlorine dioxide is another effective water disinfectant, but is not widely used. This chemical does not produce trihalomethanes nor react with ammonia. When applied in low amounts and concomitantly with chlorine it decreased significantly the formation of trihalomethanes. ${ }^{135}$ Ozonation is an alternative treatment technique, which considerably improves the quality of DW. Ozone has powerful oxidation properties and has been shown to efficiently remove microorganisms, taste and odour. Ozone proved to be very effective for the inactivation of viruses and 
Table 3 Characteristics of the main disinfectants used in DWDS ${ }^{186}$

\begin{tabular}{|c|c|c|c|c|}
\hline Chlorine & $\begin{array}{l}\text { Bacteria } \\
\text { Viruses }\end{array}$ & $\begin{array}{l}\text { Capable of producing lethal events at or near } \\
\text { the cell membrane, as well as affecting DNA. } \\
\text { In bacteria, chlorine was found to adversely } \\
\text { affect cell respiration, transport and possibly } \\
\text { DNA activity. It causes an immediate decrease } \\
\text { in oxygen utilization, damages the cell wall } \\
\text { membrane, promotes leakage through the cell } \\
\text { membrane and produces lower levels of DNA } \\
\text { synthesis. }\end{array}$ & Yes & $\begin{array}{l}\text { Trihalomethanes } \\
\text { Haloacetic acids }\end{array}$ \\
\hline Chloramines & Bacteria & $\begin{array}{l}\text { It readily reacts with amino acids. The } \\
\text { mechanism of inactivation is therefore thought } \\
\text { to involve inhibition of proteins or protein- } \\
\text { mediated processes, such as respiration. }\end{array}$ & Yes & $\begin{array}{l}\text { Trihalomethanes } \\
\text { Haloacetic acids }\end{array}$ \\
\hline Ozone & $\begin{array}{l}\text { Bacteria } \\
\text { Cryptosporidium } \\
\text { Giardia } \\
\text { Viruses }\end{array}$ & $\begin{array}{l}\text { In bacteria, it attacks the cell membrane } \\
\text { (glycoproteins, glycolipids, amino acids) and } \\
\text { disrupts enzymatic activity by acting on the } \\
\text { sulfhydryl groups of certain enzymes. Beyond } \\
\text { the cell membrane and cell wall, it may act on } \\
\text { the nuclear material and affect both purines } \\
\text { and pyrimidines in nucleic acids. In viruses, it } \\
\text { damages the viral capsid proteins and the nucleic acids. }\end{array}$ & No & $\begin{array}{l}\text { Haloacetic acids } \\
\text { Aldehydes } \\
\text { Aldo- and Ketoacids } \\
\text { Brominated DBPs } \\
\text { Hydrogen peroxide }\end{array}$ \\
\hline UV radiation & $\begin{array}{l}\text { Bacteria } \\
\text { Viruses } \\
\text { Protozoa }\end{array}$ & $\begin{array}{l}\text { Penetrates the microbial cell wall, disrupting } \\
\text { the genetic material, making reproduction impossible. }\end{array}$ & No & No \\
\hline
\end{tabular}

protozoa that form cysts. ${ }^{135}$ Another advantage is that it generates relatively few DBPs, as compared with chlorine, and leaves no taste or odour. Apart from being more expensive than chlorination, the lack of residual disinfection action in DWDS is the major drawback. ${ }^{135}$ When water contains bromide the use of ozone should be avoided as both react and form bromate, which is widely considered to be a genotoxic carcinogen. ${ }^{136}$ Another alternative is a non-chemical disinfection method, e.g., UV radiation (electromagnetic energy in the range 250-265 $\mathrm{nm}$ ). This energy destroys the microorganisms by altering their genetic material and rendering them unable to reproduce. UV radiation is a very effective disinfectant against all bacteria, viruses and protozoa cysts found in clarified waters. ${ }^{137}$ The main disadvantage is that UV leaves no residual disinfectant in the water, which is overcome by applying a second disinfectant to generate a residual amount. However, no measurable difference in biofilm biomass or pathogen incidence was verified in the transition from conventional chlorination to UV-treatment. ${ }^{138}$ The combination of physical (UV light) with chemical (chlorine and chlorine dioxide) treatments was shown to be more effective in eradicating DW biofilms than the two treatments applied separately. ${ }^{139,140}$ Recently, sodium dichloroisocyanurate (NaDCC) was proposed as alternative to sodium hypochlorite for the treatment of DW at the household level. ${ }^{141}$
NaDCC had a similar effectiveness at eliminating planktonic bacteria and was also effective in the inhibition of biofilm formation, as well as in the inactivation of existing biofilms and was comparable to sodium hypochlorite (bleach). However, NaDCC has several advantages over bleach, namely its easy ability for safe transport, its slow release and maintenance of free available chlorine levels, which may be associated with its ability to maintain a low $\mathrm{pH}$ over long periods of time. ${ }^{141}$

New and alternative techniques for disinfection and microbial control in DW have already been described. The combination of UV irradiation and direct electrolysis provides a promising approach for DW disinfection. ${ }^{142}$ Water disinfection can be carried out by acoustic and hydrodynamic cavitation. ${ }^{143}$ This method promotes the generation of very high pressures and temperatures locally, which can cause cellular damage. ${ }^{144}$ Hydrodynamic cavitation and ultrasound have also been reported as advanced disinfection technologies for DW treatment and are deemed to be environmentally sound without generating toxic residual by-products. ${ }^{145,146}$ The use of hybrid methods, namely ozone or hydrogen peroxide with cavitation, is attractive for DW disinfection. ${ }^{145,147}$

Electron-beam radiation is an environmentally-friendly technique that uses ionizing radiation produced by electron 
accelerators and has potential applications in the disinfection of DW and wastewaters. ${ }^{148-150}$ Of the well-known techniques for the simultaneous disinfection of river water and the removal of chemical pollutants, electron-beam water treatment with the use of ozone from the zone of electron-beam air radiolysis is the most reliable. ${ }^{149}$ More recently, the potential application of antimicrobial nanomaterials for water disinfection and microbial control has been reviewed. ${ }^{151}$ Several natural and engineered nanomaterials (chitosan, silver nanoparticules, photocatalytic titanium dioxide, fullerol, aqueous fullerene nanoparticles and carbon nanotubes) with strong antimicrobial properties were mentioned. Unlike conventional chemical disinfectants, these antimicrobial nanomaterials are not strong oxidants, are relatively inert in water and are not expected to produce harmful DBPs. Another report looked at the application of carbon nanotube technology for the disinfection and removal of contaminants in DW. ${ }^{152}$ A "sonocatalytic disinfection" method using ultrasound irradiation in the presence of titanium dioxide has also been reported. ${ }^{153}$ Ultrasonic irradiation is well known as a useful technique for microbial inactivation due to its chemical and physical factors. The presence of titanium dioxide, known as a photocatalyst, accelerates the generation of hydroxyl radicals during ultrasonic irradiation, inducing cell death. Recent developments in photocatalytic water treatment technology have been review by Chong et al. ${ }^{154}$ as an innovative water treatment technology. These advanced oxidation processes are based on the in situ generation of highly reactive transitory species (i.e., $\mathrm{H}_{2} \mathrm{O}_{2}, \mathrm{OH}, \mathrm{O}^{2-}, \mathrm{O}_{3}$ ) for mineralization of refractory organic compounds, water pathogens and disinfection by-products. Semiconductor photocatalytic processes have shown great potential as low-cost, environmentally-friendly and sustainable treatment technologies and align well with the "zero" waste scheme in the water/wastewater industry. The main technical barriers that impede its commercialisation remain on the post-recovery of the catalyst particles after water treatment.

More recently, a water disinfection method that uses paper impregnated with silver nanoparticles for point-of-use water treatment has been proposed. ${ }^{155}$ This technique seems to be very useful for people that are not connected to a DW network and for emergency situations following natural disasters. Lowcost filter materials (zeolite, sand, fibreglass, anion and cation resin substrates) coated with silver nanoparticles also have potential for disinfection of groundwater and production of safe DW. ${ }^{156}$ Here, a filter system with an $\mathrm{Ag} /$ cation resin substrate (that completely eliminated the pathogens tested) can be used as a potential cost-effective filter for water disinfection. The association of silver nanoparticles with the bacterial cell surface of Lactobacillus fermentum (referred to as biogenic silver) has been reported to exhibit antiviral properties. ${ }^{157}$ This study shows the potential of this membrane technology for water disinfection on a small scale.

Another application of nanomaterials for water disinfection is zero-valent iron and nanoscale zero-valent iron. It was proposed that nanoscale zero-valent iron can be applied to decentralized DWDS to improve the performance of point-ofuse devices. This technology was able to effectively remove several relevant DW contaminants, including viruses, bacteria, chlorine, DBPs and other chemicals, but it is not yet widely used. ${ }^{158}$ Excellent comprehensive reviews have been undertaken by the Eugene Cloete's group, ${ }^{159,160}$ where the knowledge of nanomaterials in water treatment, purification and disinfection was reviewed and described. The health and environmental impacts of some of the nanomaterials, particularly the extent of toxicity, is still an issue that requires additional research. ${ }^{159,161,162}$

\subsection{Targeting key microbes}

An alternative preventative strategy aims to target the key microorganisms involved in biofilm formation. ${ }^{91,163}$ In a synthetic DW biofilm composed of Acinetobacter calcoaceticus, Burkholderia cepacia, Methylobacterium spp., Mycobacterium mucogenicum, Sphingomonas capsulata and Staphylococcus spp., A. calcoaceticus had a bridging functionality in the consortium of pathogens (co-aggregated with all the other bacteria, except Methylobacterium spp.) and its presence in multispecies biofilms provided increased resistance. It is conceivable that interfering with key bacteria in the biofilm may cause dispersion. This may be achieved by interfering with the biofilm command language referred to as quorum sensing (QS). The way that cells communicate and are organized in a social community is controlled by the secretion of signalling molecules and this process is called "quorum sensing". Bacteria have the ability to signal and sense the state of population density in order to change physiological needs under different growth conditions. QS benefits the biofilm community by controlling unnecessary overpopulation and competition for nutrients. The discovery that many bacteria use QS molecules to form biofilms makes it an attractive target for their control. ${ }^{79,164,165}$ QS inhibition may represent a natural, wide spread, antimicrobial strategy that could have a significant impact on biofilm formation. ${ }^{79,166}$ For example, $N$-acyl-homoserine lactone derivatives often not only have a function in modulating QS, but may also have direct bactericidal effects towards Gram-positive species, like Bacillus, Staphylococcus, Enterococcus and others species. ${ }^{167}$ However, there are no studies on the inhibition of QS on DW biofilm prevention and control and its application may require significant efforts on the assessment of toxicity and safety of QS inhibitors. Such biological and ecological mechanisms, alone or as part of synergistic procedures, could provide a new line of efficient and targeted biofilm control strategies. ${ }^{79,168-170}$

\section{Conclusions and future perspectives}

Biofilms in DWDS are responsible for several undesirable effects in the quality of the distributed water. One of the main drawbacks of biofilms is their potential to serve as a protective niche for waterborne pathogens that are responsible for several outbreaks of disease due to contaminated DW consumption. The knowledge of the main problems that result from biofilm formation in DWDS is essential to improve the current control strategies and/or to develop more effective alternatives. The use of membrane technology to control DW 
quality will certainly increase even if this is expensive, particularly for large-scale applications. However, this is highly attractive for point-of-use DW devices. Chlorine disinfection is the main strategy used in DWDS for microbial control and it is conceivable that future DWDS disinfection strategies still persist with chlorine due to economic and final product safety aspects. However, the increased resistance of biofilms to conventional disinfection processes, and also the well-known effects of DBPs on public health, clearly proposes that novel means for DW disinfection and biofilm control are required. The progress in combinatorial chemistry, the use of engineered nanostructures and the advent of high-throughput screening methods for the assessment of large numbers of chemicals with disinfectant activity will certainly provide new and efficient DW disinfectants. Recently, a new line of DW biofilm control has emerged through the interference with some biological and ecological mechanisms involved in biofilm formation. The practical application of these strategies in the water industry is still far from possible due to the incipient knowledge of all the mechanisms promoting DW biofilm formation and resistance.

\section{Acknowledgements}

This work was supported by the Operational Programme for Competitiveness Factors - COMPETE and by FCT - the Portuguese Foundation for Science and Technology through Project Bioresist - PTDC/EBB-EBI/105085/2008 (Manuel Simões) and the post-doctoral grant SFRH/BPD/81982/2011 (Lúcia C. Simões).

\section{References}

1 U. Szewzyk, R. Szewzyk, W. Manz and K. H.vSchleifer, Annu. Rev. Microbiol., 2000, 54, 81-127.

2 WHO, Guidelines for Drinking Water Quality 4th edn, World Health Organization, 2011.

3 S. L. Percival and J. T. Walker, Biofouling, 1999, 14, 99-115.

4 S. Sharma, P. Sachdeva and J. S. Virdi, Appl. Microbiol. Biotechnol., 2003, 61, 424-428.

5 A. Huq, C. A. Whitehouse, C. J. Grim, M. Alam and R. R. Colwell, Curr. Opin. Biotechnol., 2008, 19, 244-247.

6 F. Emtiazi, T. Schwartz, S. M. Marten, P. Krolla-Sidenstein and U. Obst, Water Res., 2004, 38, 1197-1206.

7 L. Hall-Stoodley and P. Stoodley, Trends Microbiol., 2005, 13, 7-10.

8 M. Momba, R. Kfir, S. N. Venter and T. E. Cloete, Water SA, 2000, 26, 59-66.

9 L. C. Simões, M. Simões and M. J. Vieira, Water Science \& Technology: Water Supply, 2012, 12(3), 334-342.

10 G. C. Whipple, Journal of the New England Water Works Association, 1897, 12, 1-19.

11 S. C. Prescott and C. E. A. Winslow, in Elements of water bacteriology, J. Wiley \& Sons, New York, 1904.

12 B. Hastings, in Biology of Water Supply, 2nd ed., 1948, British Museum (Natural History) Economic Series, no. 7A.
13 E. E. Geldreich, Journal of the Water Pollution Control Federation, 1974, 46, 1355-1372.

14 M. J. Allen, Journal of Water Pollution Control Federation, 1979, 51, 1747-1751.

15 D. J. Reasoner, Journal of the Water Pollution Control Federation, 1983, 55, 891-895.

16 Anon, in The microbiology of water 1994: Part I - drinking water, Report on Public Health and Medical Subjects no. 71, HMSO Books, London, 1994.

17 J. T. Walker and M. Morales, Water Sci. Technol., 1997, 35, 319-323.

18 R. T. Bachmann and R. G. J. Edyvean, Biofilms, 2005, 2, 197-227.

19 S. Skraber, J. Schijven, C. Gantzer and A. M. de RodaHusman, Biofilms, 2005, 2, 105-117.

20 M. Dietrich, J. Water Health, 2006, 4, 11-16.

$21 \mathrm{H}$. Olson, R. McCleary and J. Meeker, in Modeling the Environmental Fate of Microorganisms, ed. C. J. Hurst, American Society for Microbiology, Washington, DC, 1991, pp. 255-285.

22 J.-C. Block, M. Dutang, J. Maillard and D. Reasoner, Water Supply, 1994, 12, SS1/8-SS1/12.

23 D. van der Kooij and H. R. Veenendaal, Water Supply, 1994, 12, SS1/1-SS1/7.

24 K. Camper, M. Burr, B. Ellis, P. Butterfield and C. Abernathy, J. Appl. Microbiol., 1998, 85, 1S-12S.

25 J. T. Walker, S. Ives, M. Morales, N. L. Pavey and A. A. West, Int. Biodeterior. Biodegrad., 1997, 39, 88-89.

26 D. van der Kooij, J. H. M. van Lieverloo, J. A. Schellart and P. Hiemstra, Journal of Water Services Research and Technology - Aqua, 1999, 48, 31-37.

27 N. J. Ashbolt, Toxicology, 2004, 198, 229-238.

28 UNDP, Beyond Scarcity: Power, Poverty and the Global Water Crisis, United Nations Development Programme, Human development report 2006, 2006.

29 M. A. Shannon, P. W. Bohn, M. Elimelech, J. G. Georgiadis, B. J. Mariñas and A. M. Mayes, Nature, 2008, 452, 301-310.

30 N. Gilbert, Nature, 2012, 483, 256-257.

31 S. D. Kim, J. Cho, I. S. Kim, B. J. Vanderford and S. A. Snyder, Water Res., 2007, 41, 1013-1021.

32 B. Kasprzyk-Hordern, R. M. Dinsdale and A. J. Guwy, Water Res., 2008, 42, 3498-3518.

33 E. Hrudey and E. J. Hrudey, in Lessons from recent outbreaks in affluent nations, International Water Association Publishing, London, 2004.

34 M. F. Craun, G. F. Craun, R. L. Calderon and M. J. Beach, J. Water Health, 2006, 4, 19-30.

35 P. Beaudeau, H. de Valk, V. Vaillant, C. Mannschott, C. Tillier, D. Mouly and M. Ledrans, J. Water Health, 2008, 6, 491-503.

36 M. F. Blasi, M. Carere, M. G. Pompa, E. Rizzuto and E. Funari, J. Water Health, 2008, 6, 423-432.

37 P. Karanis, C. Kourenti and H. Smith, J. Water Health, 2007, 5, 1-38.

38 S. P. Payment, Can. J. Microbiol., 1999, 45, 709-715.

39 B. Barbeau, P. Payment, J. Coallier, B. Clément and M. Prévost, Quant. Microbiol., 2000, 2, 37-54.

40 L. Gofti-Laroche, D. Demanse, J. C. Joret and D. Zmirou, J. Am. Water Works Assoc., 2003, 95, 162-172. 
41 L. Gofti-Laroche, B. Gratacap-Cavallier, D. Demanse, O. Genoulaz, J. M. Seigneurin and D. Zmirou, J. Clin. Virol., 2003, 27, 74-82.

42 M. Exner, Hygiene + Medizin, 2004, 29, 418-4227.

43 D. L. Paterson, Clin. Infect. Dis., 2006, 43, S43-S48.

44 D. Hafliger, P. Hubner and J. Luthy, Int. J. Food Microbiol., 2000, 54, 123-126.

45 S. Glaberman, J. E. Moore, C. J. Lowery, R. M. Chalmers, I. Sulaiman, K. Elwin, P. J. Rooney, B. C. Millar, J. S. Dooley, A. A. Lal and L. Xiao, Emerging Infect. Dis., 2002, 8, 631-633.

46 M.-L. Hanninen, H. Haajanen, T. Pummi, K. Wermundsen, M.-L. Katila, H. Sarkkinen, I. Miettinen and H. Rautelins, Appl. Environ. Microbiol., 2003, 69, 1391-1396.

47 B. Said, F. Wright, G. L. Nichols, M. Reacher and M. Rutter, Epidemiol. Infect., 2003, 130, 469-479.

48 T. V. Amvrosy'eva, Z. F. Bogush, O. N. Kazinets, O. V. Dyakonova, N. V. Poklonskaya, G. P. Golovnyova and R. M. Sharko, Vopr. Virusol., 2004, 49, 30-34.

49 R. Laporte, P. Pernes, P. Pronni, F. Gottrand and P. Vincent, Br. Med. J., 2004, 329, 204-205.

50 L. Maunula, I. T. Miettinen and C. H. Von Bonsdorff, Emerging Infect. Dis., 2005, 11, 1716-1721.

51 X. Garg, J. Marshall, M. Salvadori, H. R. ThiessenPhilbrook, J. Macnab, R. S. Suri, R. B. Haynes, J. Pope and W. Clark, on behalf of the Walkerton Health Study Investigators, J. Clin. Epidemiol., 2006, 59, 421-428.

52 J. Empel, K. Filczak, A. Mrowka, W. Hryniewicz, D. A. Livermore and M. Gniadkowski, J. Clin. Microbiol., 2007, 45, 2829-2834.

53 J. Hewitt, D. Bell, G. C. Simmons, M. Rivera-Aban, S. Wolf and G. E. Greening, Appl. Environ. Microbiol., 2007, 73, 7853-7857.

54 G. F. Craun, J. M. Brunkard, J. S. Yoder, V. A. Roberts, J. Carpenter, T. Wade, R. L. Calderon, J. M. Roberts, M. J. Beach and S. L. Roy, Clin. Microbiol. Rev., 2010, 23, 507-528.

55 H. M. L. Kvitsand and L. Fiksdal, Water Sci. Technol., 2010, 61, 563-571.

56 B. G. Blackburn, G. F. Craun, J. S. Yoder, V. Hill, R. L. Calderon, N. Chen, S. H. Lee, D. A. Levy and M. J. Beach, MMWR Surveill. Summ., 2004, 53, 23-45.

57 B. M. Afzal, Journal of Midwifery \& Women's Health, 2006, 51, 12-18.

58 J. L. Liang, E. J. Dziuban, G. F. Craun, V. Hill, M. R. Moore, R. J. Gelting, R. L. Calderon, M. J. Beach and S. L. Roy, MMWR Surveill. Summ., 2006, 55, 31-58.

59 WHO Europe, in Outbreaks of waterborne diseases, European Environment and Health Information System, 2009 (www.euro.who.int/ENHIS).

60 C. L. Pankhurst, N. W. Johnson and R. G. Woods, Int. Dent. J., 1998, 48, 359-368.

61 J. T. Walker, D. J. Bradshaw, M. R. Fulford, M. V. Martin and P. D. Marsh, in Chance or Necessity?, ed. P. Gilbert, D. Allison, M. Brading, J. Verran and J. Walker, BioLine, Cardiff, 2001, pp. 333-340.

62 F. F. S. Franco, D. Spratt, J. C. Leao and S. R. Porter, Biofilms, 2005, 2, 9-17.

63 G. C. du Moulin, E. C. Coleman Jr and J. Hedley-Whyte, Appl. Environ. Microbiol., 1987, 53, 1322-1326.
64 G. Pontoriero, P. Pozzoni, S. Andrulli and F. Locatelli, Nephrol., Dial., Transplant., 2003, 18, 21-25.

65 G. A. McFeters, S. C. Broadaway, B. H. Pyle and Y. Egozy, Appl. Environ. Microbiol., 1993, 59, 1410-1415.

66 H.-C. Flemming, Exp. Therm. Fluid Sci., 1997, 14, 382-391.

67 F. Riedewald, Pharmaceutical Engineering, 1997, 17, 1-7.

68 W. Harned, J. Environ. Sci., 1986, 29, 32-34.

69 S. Kim, S. E. Kim and J. S. Hwang, J. Microbiol. Biotechnol., 1997, 7, 200-203.

70 M. C. Roman and S. Minton-Summers, Life Support Biosph. Sci., 1998, 5, 45-51.

71 M. Regan, G. W. Harrington, H. Baribeau, R. D. Leon and D. R. Noguera, Water Res., 2003, 37, 197-205.

72 B. Beech and J. Sunner, Curr. Opin. Biotechnol., 2004, 15, 181-186.

73 K. Camper, Int. J. Food Microbiol., 2004, 92, 355-364.

74 F. Teng, Y. T. Guan and W. P. Zhu, Corros. Sci., 2008, 50, 2816-2823.

75 M. W. LeChevallier, T. M. Babcock and R. G. Lee, Appl. Environ. Microbiol., 1987, 53, 2714-2724.

76 J. Wingender and H.-C. Flemming, Int. J. Hyg. Environ. Health, 2011, 214, 417-423.

77 H.-C. Flemming, S. Percival and J. Walker, Water Sci. Technol.: Water Supply, 2002, 2, 271-280.

78 M. J. Vieira and L. F. Melo, Water Sci. Technol., 1995, 32, 45-52.

79 M. Simões, L. C. Simões and M. J. Vieira, LWT-Food Sci. Technol., 2010, 43, 573-583.

80 W. G. Characklis and K. C. Marshall, in Biofilms, ed. W.G. Characklis and K. C. Marshall, John Wiley \& Sons, Inc., New York, 1990.

81 F. Codony, A. M. Miranda and J. Mas, Water SA, 2003, 29, 113-116.

82 W. J. Snelling, J. E. Moore, J. P. McKenna, D. M. Lecky and J. S. G. Dooley, Microbes Infect., 2006, 8, 578-587.

83 W. M. Dunne Jr., Clin. Microbiol. Rev., 2002, 15, 155-166.

84 L. C. Simões, N. Azevedo, A. Pacheco, C. W. Keevil and M. J. Vieira, Biofouling, 2006, 22, 91-99.

85 H.-C. Flemming and J. Wingender, Nat. Rev. Microbiol., 2010, 8, 623-633.

86 T.-F. C. Mah and G. A. O’Toole, Trends Microbiol., 2001, 9, 34-39.

87 M. Simões, M. O. Pereira and M. J. Vieira, Water Res., 2005, 39, 5142-5152.

88 M. Simões, M. O. Pereira and M. J. Vieira, Water Res., 2005, 39, 478-486.

89 A. Bridier, R. Briandet, V. Thomas and F. DuboisBrissonnet, Biofouling, 2011, 27, 1017-1032.

90 G. A. Gagnon, J. L. Rand, K. C. O'Leary, A. C. Rygel, C. Chauret and R. C. Andrews, Water Res., 2005, 39, 1809-1817.

91 L. C. Simões, M. Simões and M. J. Vieira, Appl. Environ. Microbiol., 2010, 76, 6673-6679.

92 P. S. Stewart and J. W. Costerton, Lancet, 2001, 358, 135-38.

93 P. S. Stewart, J. Bacteriol., 2003, 185, 1485-1491.

94 M. Simões, M. O. Pereira, S. Sillankorva, J. Azeredo and M. J. Vieira, Biofouling, 2007, 23, 249-258.

95 P. S. Stewart and M. J. Franklin, Nat. Rev. Microbiol., 2008, 6, 199-210. 
96 T. Tolker-Nielsen and S. Molin, Microb. Ecol., 2000, 40, 75-84.

97 S. Wuertz, S. Okabe and M. Hausner, Water Sci. Technol., 2004, 49, 327-336.

98 C. D. Nadell, J. B. Xavier, S. A. Levin and K. R. Foster, PLoS Biol., 2008, 6, 171-179.

99 J. S. Webb, in: The biofilm mode of life: mechanisms and adaptations, ed. S. Kjelleberg and M. Givskov, Horizon Bioscience, Wymondham, UK, 2007, ch. 9, pp. 164-174.

100 P. S. Stewart, Biofouling, 2012, 28, 187-198.

101 F. Codony, J. Morato and J. Mas, Water Res., 2005, 39, 1896-1906.

102 S. M. September, F. A. Els, S. N. Venter and V. S. Brözel, J. Water Health, 2007, 05(2), 219-227.

103 J. M. Thomas and N. J. Ashbolt, Environ. Sci. Technol., $2011,45,860-869$.

104 T. E. Ford, Environ. Health Perspect., 1999, 107, 191-206.

105 P. Niquette, P. Servais and R. Savoir, Water Res., 2000, 34, 1952-1956.

106 N. Momba and M. A. Binda, J. Appl. Microbiol., 2002, 92, 641-648.

107 S. Srinivasan and G. W. Harringtona, Water Res., 2007, 41, 2127-2138.

108 L.-L. Zhou, Y.-J. Zhang and G.-B. Li, J. Zhejiang Univ., Sci., $A, 2009,10,725-731$.

109 T. Griebe and H.-C. Flemming, Desalination, 1998, 118, 153-156.

110 J. P. Chandy and M. L. Angles, Water Res., 2001, 35, 2677-2682.

111 P. Payment, D. P. Sartory and D. J. Reasoner, in Heterotrophic plate counts and drinking water safety: the significance of HPCs for water quality and human health, ed. J. Bartram, J. Cotruvo, M. Exner, C. Fricker and A. Glasmacher, IWA Publishing on behalf of the World Health Organization, London, 2003, pp. 20-48.

112 A. Dror-Ehre, A. Adin, G. Markovich and H. Mamane, Water Res., 2010, 44, 2601-2609.

113 J. Rogers, A. B. Dowsett, P. J. Dennis, J. V. Lee and C.W. Keevil, Appl. Environ. Microbiol., 1994, 60, 1842-1851.

114 R. F. Mueller, W. G. Characklis, W. L. Jones and J. T. Sears, Biotechnol. Bioeng., 1992, 39, 1161-1170.

115 T. Schwartz, S. Hoffmann and U. Obst, Water Res., 1998, 32, 2787-2797.

116 J. Hem and I. Skjevrak, Potential water quality deterioration of drinking water caused by leakage of organic compounds from materials in contact with the water, 20th NoDig Conference, Copenhagen, 2002.

117 Z. Dwidjosiswojo, J. Richard, M. M. Moritz, E. Dopp, H.C. Flemming and J. Wingender, Int. J. Hyg. Environ. Health, 2011, 214, 485-492.

118 J. Lehtola, I. T. Miettinen, T. Lampola, A. Hirvonen, T. Vartiainen and P. J. Martikainen, Water Res., 2005, 39, 1962-1971.

119 C. J. Kerr, K. S. Osborn, A. H. Rickard, G. D. Robson and P. S. Handley, in The Handbook of Water and Wastewater Microbiology, ed. D. Mara and N. Horan, Academic Press, London, 2003, ch. 41, pp. 757-775.

120 W. LeChevallier, C. D. Lowry and R. G. Lee, J. Am. Water Works Assoc., 1990, 82, 87-99.
121 C. D. Norton and M. W. LeChevallier, Appl. Environ. Microbiol., 2000, 66, 268-276.

122 B. Hallam, J. R. West, C. F. Forster, J. C. Powell and I. Spencer, Water Res., 2002, 36, 3479-3488.

123 O. Al-Jasser, Water Res., 2007, 41, 387-396.

124 M. N. B. Momba and P. Kaleni, Water Res., 2002, 36, 3023-3028.

125 G. M. Ayoub and L. Malaeb, Int. J. Environ. Pollut., 2006, 26, 379-397.

126 M. P. Ginige, J. Wylie and J. Plumb, Biofouling, 2011, 27, 151-163.

127 R. J. Bull, L. S. Birnbaum, K. P. Cantor, J. B. Rose, B. E. Butterworth, R. Pegram and J. Tuomisto, Fundam. Appl. Toxicol., 1995, 28, 155-166.

128 M. J. Nieuwenhuijsen, M. B. Toledano, N. E. Eaton, J. Fawell and P. Elliott, Occup. Environ. Med., 2000, 57, 73-85.

129 N. Ozdemir and A. Ucak, J. Environ. Eng., 2002, 128, 31-39.

130 J. S. Ecuru, J. Okot-Okumu and T. O. Okurut, Journal of Applied Sciences and Environmental Management, 2011, 15, 167-173.

131 C. Le Dantec, J.-P. Duguet, A. Montiel, N. Dumoutier, S. Dubrou and V. Vincent, Appl. Environ. Microbiol., 2002, 68, 1025-1032.

132 C.-W. Chang, Y.-H. Hwang, W.-Y. Cheng and C.-P. Chang, J. Appl. Microbiol., 2007, 102, 1636-1644.

133 K. H. Baker, J. P. Hegarty, B. Redmond, N. A. Reed and D. S. Herson, Appl. Environ. Microbiol., 2002, 68, 981-984.

134 J. W. A. Charrois and S. E. Hrudey, Water Res., 2007, 41, 674-682.

135 Y. Lee and S. Nam, Water Cond. Purif., 2005, 47, 1-6.

136 S. Chowdhury, M. J. Rodriguez and R. Sadiq, J. Hazard. Mater., 2011, 187, 574-584.

137 W. A. M. Hijnen, E. F. Beerendonk and G. J. Medema, Water Res., 2006, 40, 3-22.

138 J. Längmark, M. V. Storey, N. J. Ashbolt and T.A. Stenström, Water Res., 2007, 41, 3327-3336.

139 J. L. Rand, R. Hofmann, M. Z. B. Alam, C. Chauret, R. Cantwell, R. C. Andrews and G. A. Gagnon, Water Res., 2007, 41, 1939-1948.

140 H. M. Murphy, S. J. Payne and G. A. Gagnon, Water Res., 2008, 42, 2083-2092.

141 A. Morgenthau, A. M. Nicolae, A. E. Laursen, D. A. Foucher, G. M. Wolfaardt and M. Hausner, Biofouling, 2012, 28, 111-120.

142 H. Bergmann, T. Iourtchouk, K. Schöps and K. Bouzek, Chem. Eng. J., 2002, 85, 111-117.

143 L. Mezule, S. Tsyfansky, V. Yakushevich and T. Juhna, Desalination, 2009, 248, 152-159.

144 K. K. Jyoti and A. B. Pandit, Biochem. Eng. J., 2001, 7, 201-212.

145 K. K. Jyoti and A. B. Pandit, Ultrason. Sonochem., 2003, 10, 255-264.

146 P. Piyasena, M. Mohareb and R. C. McKellar, Int. J. Food Microbiol., 2003, 87, 207-216.

147 R. Chand, D. H. Bremner, K. C. Namkung, P. J. Collier and P. R. Gogate, Biochem. Eng. J., 2007, 35, 357-364.

148 M. H. Sampa, S. I. Borrely, B. L. Silva, J. M. Vieira, P. R. Rela, W. A. P. Calvo, R. C. Nieto, C. L. Duarte, H. E. B. Perez, E. S. Somessari and A. B. Lugao, Radiat. Phys. Chem., 1995, 46, 1143-1146. 
149 N. A. Strokin, High Energy Chem., 2007, 41, 1-4.

150 Y. A. Maruthi, N. L. Das, K. Hossain, K. S. S. Sarma, K. P. Rawat and S. Sabharwal, Applied Water Science, 2011, 1, 49-56.

151 Q. Li, S. Mahendra, D. Y. Lyon, L. Brunet, M. V. Liga, D. Li and P. J. J. Alvarez, Water Res., 2008, 42, 4591-4602.

152 V. K. K. Upadhyayula, S. Deng, M. C. Mitchell and G. B. Smith, Sci. Total Environ., 2009, 408, 1-13.

153 N. Shimizu, K. Ninomiya, C. Ogino and M. M. Rahman, Biochem. Eng. J., 2010, 48, 416-423.

154 M. N. Chong, B. Jin, C. W. K. Chow and C. Saint, Water Res., 2010, 44, 2997-3027.

155 T. A. Dankovich and D. G. Gray, Environ. Sci. Technol., 2011, 45, 1992-1998.

156 L. Mpenyana-Monyatsi, N. H. Mthombeni, M. S. Onyango and M. N. B. Momba, Int. J. Environ. Res. Public Health, 2012, 9, 244-271.

157 B. De Gusseme, T. Hennebel, E. Christiaens, H. Saveyn, K. Verbeken, J. P. Fitts, N. Boon and W. Verstraete, Water Res., 2011, 45, 1856-1864.

158 B. I. Kharisov, H. V. R. Dias, O. V. Kharissova, V. M. Jiménez-Pérez, B. O. Pérez and B. M. Flores, $R S C$ Adv., 2012, 2, 9325.

159 J. Theron, J. A. Walker and T. E. Cloete, Crit. Rev. Microbiol., 2008, 34, 43-69.

160 M. Botes and T. E. Cloete, Crit. Rev. Microbiol., 2010, 36, 68-81.

161 D. B. Warheit, T. R. Webb, C. M. Sayes, V. L. Colvin and K. L. Reed, Toxicol. Sci., 2006, 91, 227-236.

162 K. Schmid and M. Riediker, Environ. Sci. Technol., 2008, 42, 2253-2260.

163 L. C. Simões, M. Simões and M. J. Vieira, Appl. Environ. Microbiol., 2008, 74, 1259-1263.

164 G. Dunstall, M. T. Rowe, G. B. Wisdom and D. Kilpatrick, J. Dairy Res., 2005, 72, 276-280.

165 B. Rasmussen, M. E. Skindersoe, T. Bjarnsholt, R. K. Phipps, K. B. Christensen, P. O. Jensen, J. B. Anderson, B. Koch, T. O. Larsen, M. Hentzer, L. Eberl, N. Høiby and M. Givskov, Microbiology, 2005, 151, 1325-1340.

166 Y.-H. Dong, A. R. Gusti, Q. Zhang, J.-L. Xu and L.H. Zhang, Appl. Environ. Microbiol., 2002, 68, 1754-1759.

167 G. F. Kaufmann, R. Sartorio, S. H. Lee, C. J. Rogers, M. M. Meijler, J. A. Moss, B. Clapham, A. P. Brogan, T. J. Dickerson and K. D. Janda, Proc. Natl. Acad. Sci. U. S. A., 2005, 102, 309-314.

168 K. Singh, M. R. Parsek, P. E. Greenberg and M. J. Welsh, Nature, 2002, 417, 552-555.

169 E. Banin, M. L. Vasil and P. Greenberg, Proc. Natl. Acad. Sci. U. S. A., 2005, 102, 11076-11081.
170 D. J. Musk, D. A. Banko and P. J. Hergenrother, Chem. Biol., 2005, 12, 789-796.

171 J. Summers, Soho - A History of London's Most Colourful Neighborhood, Bloomsbury Pub Ltd, 1989.

172 G. S. Bowen and M. A. McCarthy, Am. J. Epidemiol., 1983, 117, 695-705.

173 N. Egoz, S. Shihab, L. Leitner and M. Lucian, Isr. J. Med. Sci., 1988, 24, 640-643.

174 E. B. Hayes, T. D. Matte, T. R. O’Brien, T. W. McKinley, G. S. Logsdon, J. B. Rose, B. L. Ungar, D. M. Word, P. F. Pinsky and M. L. Cummings, N. Engl. J. Med., 1989, 320, 1372-1376.

175 W. R. Mac Kenzie, N. J. Hoxie, M. E. Proctor, M. S. Gradus, K. A. Blair, D. E. Peterson, J. J. Kazmierczak, D. G. Addiss, K. R. Fox, J. B. Rose and J. P. Davis, N. Engl. J. Med., 1994, 331, 161-167.

176 Centers for Disease Control and Prevention (CDC), $M M W R$ Morb. Mortal. Wkly. Rep., 1998, 47, 856-860.

177 M. Kuusi, J. P. Nuorti, M.-L. Hänninen, M. Koskela, V. Jussila, E. Kela, I. Miettinen and P. Ruutu, Epidemiol. Infect., 2005, 133, 593-601.

178 E. Hrudey and R. Walker, Opflow, 2005, 3(1), 4-7.

179 K. Nygård, M. Torvén, C. Ancker, S. B. Knauth, K.O. Hedlund, J. Giesecke, Y. Andersson and L. Svensson, Emerging Infect. Dis., 2003, 9, 1548-1552.

180 K. Nygård, B. Schimmer, Ø. Søbstad, A. Walde, I. Tveit, N. Langeland, T. Hausken and P. Aavitsland, BMC Public Health, 2006, 6, 141.

181 C. E. O’Reilly, A. B. Bowen, N. E. Perey, J. P. Sarisky, C. A. Shepherd, M. D. Miller, B. C. Hubbard, M. Herring, S. D. Buchanan, C. C. Fitzgerald, V. Hill, M. J. Arrowood, L. X. Xiao, R. M. Hoekstra, E. D. Mintz and M. F. Lynch, Outbreak Working Group, Clin. Infect. Dis., 2007, 44, 506-512.

182 L. S. Vestergaard, K. E. Olsen, C. R. Stensvold, B. E. Böttiger, M. Adelhardt, M. Lisby, L. Mørk and K. Mølbak, EuroSurveillence, 2007, 12, 3164.

183 E. Karon, K. D. Hanni, J. C. Mohle-Boetani, R. A. Beretti, V. R. Hill, M. Arrowood, S. P. Johnston, L. Xiao and D. J. Vugia, Epidemiol. Infect., 2011, 139, 713-717.

184 M. Riera-Montes, K. B. Sjölander, G. Allestam, E. Hallin, K.-O. Hedlund and M. Löfdahl, Epidemiol. Infect., 2011, 139, 1928-1935.

185 R. Bhunia and S. Ghosh, Trans. R. Soc. Trop. Med. Hyg., 2011, 105, 214-219.

186 EPA, Alternative Disinfectants and Oxidants. Guidance Manual, US Environmental Protection Agency, Office of Water, 1999.

187 L. C. Simões, M. Simões, R. Oliveira and M. J. Vieira, J. Basic Microbiol., 2007, 47, 174-183. 